\title{
Predictors of School Effectiveness: School Culture and Climate of Sekolah Kebangsaan Malaysia
}

Thiruchelvan Koundyannan, Suhaida Abdul Kadir, Ramli Basri and Ahmad Fauzi Mohd Ayub

To Link this Article: http://dx.doi.org/10.6007/IJARBSS/v10-i11/8148

DOI:10.6007/IJARBSS/v10-i11/8148

Received: 21 September 2020, Revised: 23 October 2020, Accepted: 10 November 2020

Published Online: 29 November 2020

In-Text Citation: (Koundyannan, Abdul Kadir, Basri, \& Ayub, 2020)

To Cite this Article: Koundyannan, T., Abdul Kadir, S., Basri, R., and Ayub, A. F. M. (2020). Predictors of School Effectiveness: School Culture and Climate of Sekolah Kebangsaan Malaysia. International Journal of Academic Research in Business and Social Sciences. 10(11), 866-878.

Copyright: (c) 2020 The Author(s)

Published by Human Resource Management Academic Research Society (www.hrmars.com)

This article is published under the Creative Commons Attribution (CC BY 4.0) license. Anyone may reproduce, distribute, translate and create derivative works of this article (for both commercial and non-commercial purposes), subject to full attribution to the original publication and authors. The full terms of this license may be seen

at: http://creativecommons.org/licences/by/4.0/legalcode

Vol. 10, No. 11, 2020, Pg. 866 - 878

Full Terms \& Conditions of access and use can be found at http://hrmars.com/index.php/pages/detail/publication-ethics 


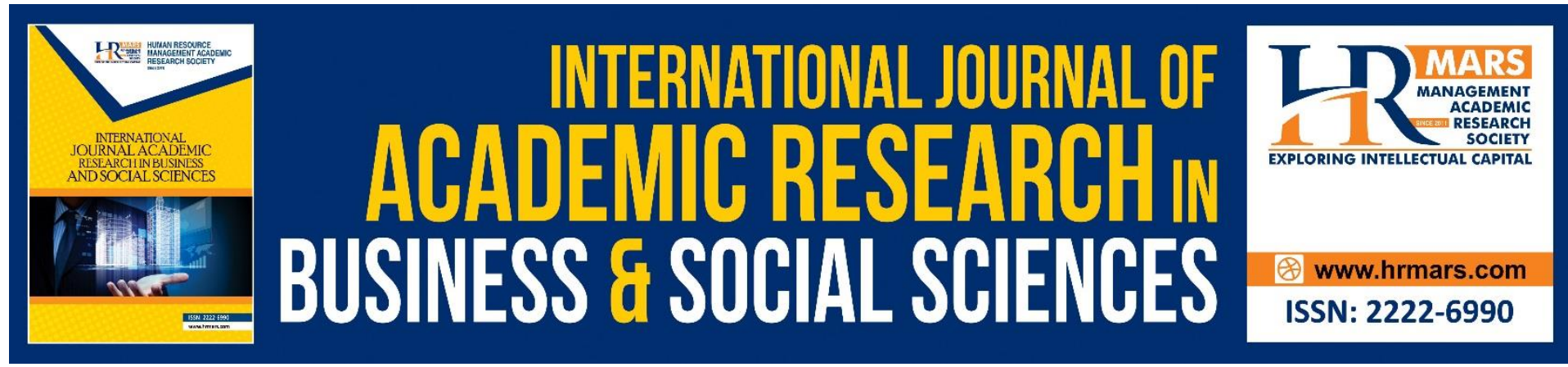

\title{
Predictors of School Effectiveness: School Culture and Climate of Sekolah Kebangsaan Malaysia
}

\section{Thiruchelvan Koundyannan, Suhaida Abdul Kadir, Ramli Basri and Ahmad Fauzi Mohd Ayub}

Faculty of Educational Studies, Universiti Putra Malaysia, MALAYSIA

Email: suhaida@upm.edu.my

\begin{abstract}
This study was conducted to examine the school culture and climate dimensions as contribution factors of school effectiveness. Stepwise multiple linear regression analysis was used to test the school effectiveness contribute factors. Three hundred fifty-three (353) teachers from 84 primary schools in Peninsular Malaysia from Sekolah Kebangsaan (SK) participated in this study. Data were collected using the School Culture Survey (Gruenert, 1998, School Climate Instrument (Ross and Lowther, 2003) and School Effectiveness Instrument (Lezotte \& Snyder, 2011). The results of the stepwise multiple linear regression analysis show that the dimension of school culture collaborative leadership, unity of purpose, learning partnership and teacher's collaboration contributed for $47.0 \%$ variance changes of school effectiveness. The dimension of school climate which is leadership, instruction, expectations and environment contributed $54.8 \%$ variance changes of school effectiveness. The overall results of stepwise multiple linear regression analysis showed that the school climate influence more compare the school culture. Both combination significantly contributed $52.5 \%$ variance changes of school effectiveness. The cross-sectional method limits data collection to one point in time. This study adds to a better understanding of how the combinations of school culture and climate dimensions contribute in interrelated to improve school effectiveness among primary schools. The overall thrust of this empirical study, which is to investigate the contribution of both school culture and climates dimension as influence factor of school effectiveness. This study highlights to which extent the both constructs dimensions contribute in helping to improve school effectiveness indirectly in school management. To examine the dominant of school culture and climate as contributing factor of school effectiveness.
\end{abstract}

Keyword: School Culture, School Climate, School Effectiveness.

\section{Introduction}

Education system in Malaysia need to address challenges in creating work-ready graduates with a balance of human capital and ability to compete internationally. Improving standards and quality in education need to be initiated as early as from primary school levels. School management plays a crucial role in improving the performance of the students by monitoring 
the school culture and climate. The Malaysian Education Blueprint (PPPM 2013-2025), has outlined guidelines on school climate management. The second wave of the School Transformation Program 2025 (TS25), emphasizes that the 'Teaching and Learning Environment' is an important aspect for improving school effectiveness (Abdul Manaf \& Che Zulkifli, 2016). The Malaysian education system will change from school based education to a system that seeks the involvement of parents and communities towards ensuring that every pupil enjoys the most conducive and effective learning environment.

School culture and climate influence every aspect of the school function effectiveness. School culture and climate shared by stakeholders provide sustainability of objective achievement (Lewis, Asberry, DeJarnett \& King, 2016). Student achievement will continue to improve in schools that foster the professional learning community among teachers by practicing school cultural and climate. Hence, leadership direct and indirect needs to shape the school cultural and climate situation for school improvement. In this process, school leadership becomes a mediator in shaping school culture and climate (Carpenter, 2015; Bellibas \& Liu, 2018).

Regression analysis is used for prediction and forecasting influence of variable. Regression analysis is also used to predict which dimension among the independent variables is related to the dependent variable and to identify the forms of these relationships (Diehr \& Hoflin, 1974). This study will identify the factors of influence in this model between school culture dimensions and school climate dimensions.

\section{Objectives}

There were three main objectives focus in this research. The purpose of this study was to determine:

i. School culture dimensions as predicable factor of school effectiveness at SK.

ii. School climate dimensions as predicable factor of school effectiveness at SK.

iii. Contribution of school culture and climate variable as predicable factor of school effectiveness at SK.

\section{Conceptual Framework}

This study was designed based on the theory of organization culture (Schein, 1992) and school climate (Anderson, 1982). It defines both school culture and climate as independent variables. The School Culture Survey (Gruenert, 1998) and School Climate Instrument (Ross and Lowther, 2003), are used to gain information for this study. Theory of School Effectiveness and Improvement (Hargreaves, 2001) also applied as tie for this research. The figure 1 , shows the combination of theory of this research: 


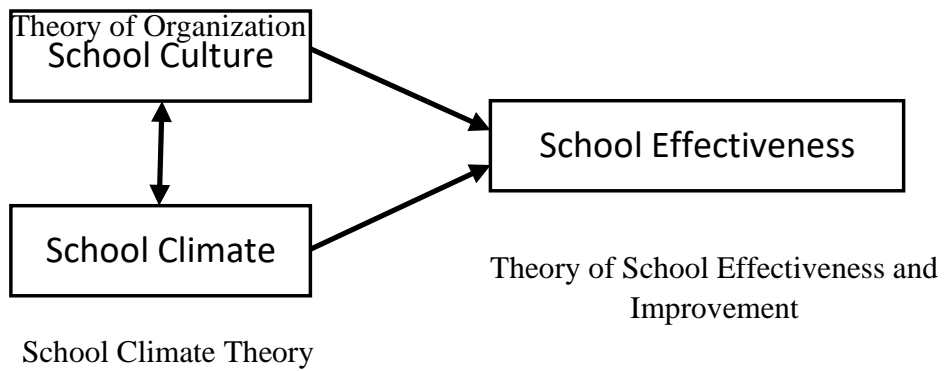

Figure 1: Theoretical Framework

\section{Literature Review and Hypothesis Development}

School culture and climate have been increasingly dramatic in recent years in the management of the education system. The both elements are seen as a shield in school management and administration in determining school effectiveness; and contributes largely in ensuring students' achievements (Gonder \& Hymes, 1994). Systematic school management on the culture and climate improves student achievement and contributes to student achievement. The school culture and climate are said to be the essence of the soul and body which attracts teachers and students towards the school that wants to be part of it. This school culture and climate attraction influence student achievement (Wang, Haertel \& Walberg, 1997).

Organizational culture is the basic concept in management theory. In the present study the management area assumes that organizational culture includes assumptions, attitudes, beliefs, rituals, traditions, knowledge, languages, norms and values shared by all members in an organization (Schein, 1985). Culture also describes a way of life that gives meaning and value not only in art or learning but also in community institutions and describing behavior (Bates, 1987). Culture is interpreted as a behavior and human behavior that reflects their values, customs and ways of life which include aspects of thinking, attitudes, beliefs and actions (Gruenert, 2000). School culture can be seen in a situation where school children comprising students, staff and parents engage in school activities and programs that illustrate the cultural characteristics of the ethos (Clarke, Hall, Jefferson \& Roberts, 1976).

The school environment interacts complexly in influencing students, staff and family members in appreciating the school. Based on Anderson (1982), there are three main dimensions of the School climate that's physical, social, and elemental aspects of trust, value and sharing of information. Based on the two explanations it has the connection in terms of its aspect. School climate reflects the physical and psychological aspects of a school that seeks to create and provides a conducive environment for teaching and learning. Howard (1974), describes the school climate as a social and cultural state of the school that affects the behavior of people in it.

Studies shows that there is a relationship between organizational culture and climate, poor management affects the performance of employees and services rendered negatively affecting customers (Glisson \& Green, 2006; Patterson, Dulmus \& Maguin, 2012). This is related to educational institutions as organizations and students as customers. Studies on organizational culture and climates recently have provided a clear indication that weak 
management of organizational culture and climate will affect the quality of school effectiveness. So the management of school cultural and climate will have an impact on the performance of teachers and student's achievement indirectly. In order to ensure that best practices and quality outcomes the school cultural and climate need to be restored (Glisson, 2007; Glisson \& Green, 2012).

The analysis of this study focuses on the correlation between school cultural dimensions and school climate dimensions and also contribution factor for school effectiveness. Both of these variables have a relationship in various aspects that affect school achievement (Patterson, Dulmus, Maguin \& Critalli, 2014). The School Culture Survey instrument developed by Gruenert, (1998) used. in identifying the relationship between these dimensions.

This questionnaire was designed for school teachers to measure the level of school culture as perceived by them. This instrument consists of 35 items divided into six main dimensions: collaborative leadership with eleven items, teacher's collaboration with six items, professional development with five items, unity of purpose with five items, collegial support with four items and learning partnership four items. All this dimensions and items contribute as factor influence for school effectiveness (Duan, Du \& Yu, 2018).

Gruenert (1998), identified six dimensions to describe the collaborative school culture which is describing collaborative leadership as school leaders who establish and maintain collaborative relationships with school staff; teacher collaboration concerns working together and sharing pedagogical information; unity of purpose refers to the school mission and its influence on teaching; professional development encompasses all types of teachers learning to maintain current knowledge about educational practices; collegial support which includes teachers' willingness to help each other when there is a problem; and learning partnership refers to cooperation between teachers and parents based on common expectations towards student achievements.

School climate is measured using the School Climate Inventory ( $\mathrm{SCl}$ ) developed by Ross and Lowther (2003), which relates to school effectiveness. In a study, there were some findings relating to school climate. The strongest finding was related to involvement. Involvement is defined as the amount of parent and community collaboration which occurs within the school. Within the school climate aspect, the community and parent involvement was positively correlated with student academic achievement (Ross \& Lowther, 2003). The inventory helps school leaders gauge school personnel perceptions and address climaterelated factors that hinder a school's effectiveness. The $\mathrm{SCl}$ includes seven dimensions that are both theoretically and empirically linked with effective school organization climates. The seven dimensions are based on collaboration, environment, expectations, instruction, involvement, leadership and order. For example, environment refers to a positive learning environment and involvement to parent and community engagement with the school. The survey is intended for school staff and consists of 49 items. All the dimension has seven items accordingly. The purpose of this study is to determine the relationship between school culture and climate at primary schools. Correlation between school culture and climate dimensions are also will be test. Additionally, study also aims to examine the influence of factors in the school culture dimensions and school climate dimensions for school effectiveness in national school's trough stepwise multiple linear regression. 


\section{Methodology}

This is a survey study, participated by a total of 353 teachers from Sekolah Kebangsaan (SK). Data for this study were collected using the School Culture Survey Instrument (Gruenert, 1998), School Climate Instrument (Ross \& Lowther, 2003) and School Effectiveness Instrument (Lezotte and Snyder, 2011). The instrument for school culture has six dimensions of collaborative leadership, teacher collaboration, professional development, collegial support, unity of purpose and learning partnership. The school climate instrument has seven dimensions based on collaboration, environment, expectations, instruction, involvement, leadership and order. The data obtained from the questionnaire were analyzed using the SPSS version 24. The use of mean value is a widely used method to describe the responses of all participants to the item in an instrument (Cresswell, 2012).

\section{Measures}

Table 1, explain in sum, 353 teachers from SK schools in peninsular Malaysia were involved in the survey. In terms of gender, there were $35.1 \%$ male teachers and $64.9 \%$ female teachers. In terms of experience, a total of 10.5\% experienced teachers taught between 1 to 5 years, $22.1 \%$ had 6 and 10 years of experience, $22.7 \%$ had 11 to 15 years of experience, $12.2 \%$ had 16 to 20 years of experience and $32.6 \%$ had 20 years of experience or more. In terms of academic qualifications, $12.2 \%$ of teachers qualified with certificates/ diplomas, $80.2 \%$ of teachers qualified with a bachelor's degree, $7.4 \%$ of teachers qualified with a bachelor's degree and $0.3 \%$ teachers with Doctorate.

Table 1. Respondent Profile

\begin{tabular}{llcc}
\hline \multicolumn{1}{c}{ Item } & \multicolumn{1}{c}{ Category } & Respondent & $\begin{array}{c}\text { Percentage } \\
\text { (\%) }\end{array}$ \\
\hline Gender & Male & 124 & 35.1 \\
& Female & 229 & 64.9 \\
\hline Teaching & $\leq 5$ & 37 & 10.5 \\
Experience & 6 - 10 Years & 78 & 22.1 \\
& $11-15$ Years & 80 & 22.7 \\
& 16 - 20 Years & 43 & 12.2 \\
& $\geq 20$ Years & 115 & 32.6 \\
\hline Academic & Certificate/Diploma & 43 & 12.2 \\
Qualification & Degree & 283 & 80.2 \\
& Masters & 26 & 7.4 \\
& Doctorate & 1 & 0.3 \\
\hline
\end{tabular}

\section{Analysis}

\section{School Culture Factor That Influence School Effectiveness}

Table 2, shows that collaborative leadership, unity of purpose, learning partnership and teacher's collaboration have significant beta $(\beta)$ values. This means that each of these variables explained the variance in school effectiveness significantly after the influence of the other variables was statistically controlled through multiple regression analysis. Professional development and collegial support were not included in the regression model because these variables had $\beta$ values that were too small and insignificant after the influence of other variables were controlled (Chua, 2009). 
Table 2. School Culture Dimensions

\begin{tabular}{lll}
\hline Dimension & Beta & Sig. \\
\hline Collaborative Leadership & $\beta=.274^{*}$ & .000 \\
Unity of Purpose & $\beta=.214^{*}$ & .000 \\
Learning Partnership & $\beta=.178^{*}$ & .000 \\
Teacher's Collaboration & $\beta=.143^{*}$ & .009 \\
Professional Development & $\beta=.065$ & .235 \\
Collegial Support & $\beta=.039$ & .428 \\
\hline
\end{tabular}

Note: Significant at level ${ }^{*} p<0.05$

The results of the multiple regression analysis in table 3 and 4 , show that the change in the four school culture variables included in the regeneration model follows a significant $\beta$ value. Collaborative Leadership $(\beta=.565, p<0.5)$ significantly contributed as much as $31.9 \%\left(R^{2}=.319\right)$ changes in variance $[F(1,351)=164.179, p<0.5]$. The combination of collaborative leadership $(\beta=.399, p<0.5)$ and unity of purpose $(\beta=.351, p<0.5)$ contributed $41.4 \%\left(R^{2}=.414\right)$ changes in variance $[F(2,350)=123.751, p<0.5]$. Then the combination of collaborative leadership $(\beta$ $=.337, p<0.5)$, unity of purpose $(\beta=.287, p<0.5)$ and learning partnership $(\beta=.183, p<0.5)$ contributed $43.6 \%\left(R^{2}=.436\right)$ change in variance $[\mathrm{F}(3,349)=89.937, \mathrm{p}<0.5]$. Finally the combination of collaborative leadership $(\beta=.311, p<0.5)$, unity of purpose $(\beta=.245, p<0.5)$, learning partnership $(\beta=.126, p<0.5)$ and teacher's collaboration contributed $47.0 \%\left(R^{2}=.470\right)$ change in variance $[F(4,348)=77.080, p<0.5]$. The regression equation is formulated as follows:

$Y=1.797+0.212_{1}+0.153_{2}+0.090_{3}+0.132_{4}$

The results of the stepwise multiple regression analysis show that the P4 regression model (collaborative leadership, unity of purpose, learning partnership and teacher's collaboration) contributed for $47.0 \%\left(R^{2}=.470\right)$ changes in variance in school effectiveness $[F(4,348)=77.080, p<0.5]$. The influence of collaborative leadership $(\beta=.311, p<.05)$ was highest, followed by unity of purpose $(\beta=.245, p<.05)$, teacher's collaboration $(\beta=.211, p<.05)$ and learning partnership $(\beta=.126, p<.05)$. School culture contributes in predicting the school effectiveness in primary schools.

Table 3. Linear Regression of School Culture as Predictor

\begin{tabular}{llllrrr}
\hline Model & $\boldsymbol{R}$ & $\boldsymbol{R}^{\mathbf{2}}$ & ${ }^{\wedge} \boldsymbol{R}^{\mathbf{2}}$ & \multicolumn{1}{c}{$\mathbf{d f}$} & \multicolumn{1}{c}{$\mathbf{F}$} & Sig. \\
\hline Collaborative Leadership & .565 & .319 & .317 & 1 & 164.179 & .000 \\
& & & & 351 & & \\
& & & & 352 & & \\
\hline Unity of Purpose & .644 & .414 & .411 & 2 & 123.751 & .000 \\
& & & & 350 & & \\
\hline Learning Partnership & .660 & .436 & .431 & 352 & & \\
& & & & 349 & & \\
& & & & 352 & & \\
\hline Teacher's Collaboration & .685 & .470 & .464 & 4 & 77.080 & .000 \\
& & & & 348 & & \\
& & & & 352 & & \\
\hline
\end{tabular}

Note: Significant at level $p<0.05$ 
INTERNATIONAL JOURNAL OF ACADEMIC RESEARCH IN BUSINESS AND SOCIAL SCIENCES Vol. 10, No. 11, 2020, E-ISSN: 2222-6990 ๑ 2020 HRMARS

Table 4. Coefficient Values for School Culture Factor as Predictors

\begin{tabular}{clrrrr}
\hline Model & \multicolumn{1}{c}{ Variable } & B & Std.Error & Beta & \multicolumn{1}{c}{ t } \\
\hline P1 & Constant & 2.675 & .125 & & 21.331 \\
& Collaborative & .385 & .030 & .565 & 12.813 \\
& Leadership & & & & \\
\hline P2 & Constant & 2.172 & .134 & & 16.185 \\
& Collaborative & .272 & .032 & .399 & 8.601 \\
& Leadership & .220 & .029 & .351 & 7.556 \\
& Unity of Purpose & & & & \\
\hline P3 & Constant & 1.982 & .142 & & 14.001 \\
& Collaborative & .230 & .033 & .337 & 6.933 \\
& Leadership & .179 & .031 & .287 & 5.874 \\
& Unity of Purpose & .130 & .036 & .183 & 3.672 \\
& Learning Partnership & & & & \\
\hline P4 & Constant & 1.797 & .143 & & 12.565 \\
& Collaborative & .212 & .032 & .311 & 6.543 \\
& Leadership & .153 & .030 & .245 & 5.077 \\
& Unity of Purpose & .090 & .036 & .126 & 2.521 \\
& Learning Partnership & .132 & .028 & .211 & 4.707 \\
& Teacher's & & & & \\
& Collaboration & & & & \\
\hline
\end{tabular}

Dependent Variable: School Effectiveness, $P=$ Predicable Variable

\section{School Climate Factor That Influence School Effectiveness}

Table 5, shows that leadership, instruction, expectations and environment have significant beta $(\beta)$ values. This means that each of these variables explained the variance in school effectiveness significantly after the influence of the other variables was statistically controlled through multiple regression analysis. Collaboration, involvement and order were not included in the regression model because these variables had $\beta$ values that were too small and insignificant after the influence of other variables.

Table 5. School Climate Dimensions

\begin{tabular}{lll}
\hline Dimension & Beta & Sig. \\
\hline Leadership & $\beta=.422^{*}$ & .000 \\
Instruction & $\beta=.182^{*}$ & .000 \\
Expectations & $\beta=.145^{*}$ & .003 \\
Environment & $\beta=.128^{*}$ & .019 \\
Collaboration & $\beta=.058$ & .328 \\
Involvement & $\beta=-.009$ & .851 \\
Order & $\beta=-.026$ & .623 \\
\hline
\end{tabular}

Note: Significant at level $p<0.05$

The results of the multiple regression analysis in table 6 and 7, showed that four school climate variables were included in the regression model according to significant $\beta$ values. Leadership $(\beta=.678, p<0.5)$ contribute for a significant $46.0 \%\left(R^{2}=.460\right)$ variance change $[F(1,351)=298.779, p<0.5]$. The combination of leadership $(\beta=535, p<0.5)$ and instruction $(\beta=.276, p<0.5)$ contribute for $51.5 \%\left(R^{2}=.515\right)$ variance change $[F(2,350)=186.196, p<0.5]$. 
Subsequent combinations of leadership $(\beta=.485, p<0.5)$, instruction $(\beta=.206, p<0.5)$ and expectations $(\beta=.176, \quad p<0.5)$ accounted for $53.6 \% \quad\left(R^{2}=.536\right)$ variance change $[F(3,349)=134.195, p<0.5]$. Finally, the combination of leadership $(\beta=.435, p<0.5)$, instruction $(\beta=.177, p<0.5)$, expectations $(\beta=.139, p<0.5)$ and environment $(\beta=.147, p<0.5)$ accounted for $54.8 \%\left(R^{2}=.548\right)$ variance change $[\mathrm{F}(4,348)=105.530, p<0.5]$. The regression equation is given as follows:

$Y=1.375+0.353_{1}+0.128_{2}+0.098_{3}+0.113_{4}$

The results of the stepwise multiple regression analysis showed that the $\mathrm{P} 4$ regression model (leadership, instruction, expectations and environment) contributed $54.8 \%\left(R^{2}=.548\right)$ of the variance in school effectiveness $[F(4,348)=105.530, p<0.5]$. Leadership influence $(\beta=.435$, $p<.05)$ was highest, followed by instruction $(\beta=.177, p<.05)$, environment $(\beta=.147, p<.05)$ and expectations $(\beta=.139, p<.05)$. School climate contributes to predicting school effectiveness in primary schools.

Table 6. Linear Regression Predictor Of School Climate

\begin{tabular}{|c|c|c|c|c|c|c|}
\hline Model & $R$ & $R^{2}$ & ${ }^{\wedge} R^{2}$ & df & $\mathbf{F}$ & Sig. \\
\hline \multirow{3}{*}{ Leadership } & .678 & .460 & .458 & 1 & 298.779 & .000 \\
\hline & & & & 351 & & \\
\hline & & & & 352 & & \\
\hline \multirow[t]{3}{*}{ Instruction } & .718 & .515 & .513 & 2 & 186.196 & .000 \\
\hline & & & & 350 & & \\
\hline & & & & 352 & & \\
\hline \multirow[t]{3}{*}{ Expectations } & .732 & .536 & .532 & 3 & 134.195 & .000 \\
\hline & & & & 349 & & \\
\hline & & & & 352 & & \\
\hline \multirow[t]{3}{*}{ Environment } & .740 & .548 & .543 & 4 & 105.530 & .000 \\
\hline & & & & 348 & & \\
\hline & & & & 352 & & \\
\hline
\end{tabular}

Note: Significant at level $p<0.05$

Table 7. Coefficient Values for School Climates Factor as Predictor

\begin{tabular}{clrccc}
\hline Model & Variable & B & Std.Error & Beta & t \\
\hline P1 & Constant & 2.006 & .132 & & 15.228 \\
& Leadership & .551 & .032 & .678 & 17.285 \\
\hline P2 & Constant & 1.633 & .138 & & 11.834 \\
& Leadership & .434 & .035 & .535 & 12.293 \\
& Instruction & .199 & .031 & .276 & 6.342 \\
\hline P3 & Constant & 1.485 & .141 &. & 10.556 \\
& Leadership & .394 & .036 & .485 & 10.880 \\
& Instruction & .149 & .033 & .206 & 4.465 \\
& Expectations & .124 & .032 & .176 & 3.891 \\
\hline P4 & Constant & 1.375 & .143 & & 9.586 \\
& Leadership & .353 & .038 & .435 & 9.278 \\
& Instruction & .128 & .034 & .177 & 3.803 \\
& Expectations & .098 & .033 & .139 & 3.012 \\
& Environment & .113 & .036 & .147 & 3.100 \\
\hline
\end{tabular}

Dependent Variable: School Effectiveness, $P=$ Predicable Variable 


\section{School Culture and Climate That Influence School Effectiveness}

Table 8 . shows that both school culture and climate have significant beta $(\beta)$ values. This means that each of these variables explained the variance in school effectiveness significantly after the influence of the other variables was statistically controlled through multiple regression analysis.

Table 8. School Culture and School Climate Variables

\begin{tabular}{lcc}
\hline Variable & Beta & Sig. \\
\hline School culture & $\beta=.399^{*}$ & .000 \\
School climate & $\beta=.367^{*}$ & .000 \\
\hline
\end{tabular}

Note: Significant at level $p<0.05$

The results of the multiple regression analysis in table 9 and 10 shows that school culture variables and school climate are included in the regression model. School culture $(\beta=.689$, $p<0.5)$ contributed significantly to $47.4 \%\left(R^{2}=.477\right)$ variance change $[\mathrm{F}(1,351)=316.610$, $p<0.5]$. The combination of school culture $(\beta=.399, p<0.5)$ and school climate $(\beta=.367, p<0.5)$ significantly contributed $52.5 \%\left(R^{2}=.525\right)$ of the variance change $[F(2,350)=193.511, p<0.5]$. The regression equation is given as follows:

$Y=1.282+0.352_{1}+0.370_{2}$

The results of the stepwise multiple regression analysis showed that school culture influence $(\beta=.399, p<.05)$ higher than School climate $(\beta=.367, p<.05)$. This model contributes to predicting $52.5 \%$ impact of school culture and climate on school effectiveness.

Table 9. Linear Regression Predictor of School Culture and School Climate

\begin{tabular}{llllrrc}
\hline Model & $\boldsymbol{R}$ & $\boldsymbol{R}^{\mathbf{2}}$ & ${ }^{\wedge} \boldsymbol{R}^{\mathbf{2}}$ & \multicolumn{1}{c}{$\mathbf{d f}$} & $\boldsymbol{F}$ & \multicolumn{1}{c}{ Sig. } \\
\hline School culture & .689 & .474 & .473 & 1 & 316.610 & .000 \\
& & & & 351 & & \\
& & & & 352 & & \\
\hline School climate & .725 & .525 & .522 & 2 & 193.511 & .000 \\
& & & & 350 & & \\
& & & & 352 & & \\
\hline
\end{tabular}

Note: Significant at level $p<0.05$

Table 10. Coefficient Values of School Culture and School Climate

\begin{tabular}{clrccc}
\hline Model & \multicolumn{1}{c}{ Variable } & B & Std.Error & Beta & t \\
\hline P1 & Constant & 1.721 & .144 & & 11.953 \\
& School culture & .608 & .034 & .689 & 17.794 \\
\hline P3 & Constant & 1.282 & .155 & & 8.295 \\
& School culture & .352 & .053 & .399 & 6.662 \\
& School climate & .370 & .060 & .367 & 6.123 \\
\hline
\end{tabular}

Note: $p<0.05$, Dependent Variable: School Effectiveness 


\section{Discussion}

This study was carried out to determine the relationship between school culture and climate in primary schools and investigate the influence of school culture factors and school climate factors on school effectiveness. This study explain that the school culture and climate contribute for school effectiveness at primary schools (Gonder \& Hymes, 1994). For the school climate variable regression model with leadership, instruction, expectations and environment contribute $54.8 \%$ changes in variance of school effectiveness. School climate contributes to predicting school effectiveness in primary schools (Thiruchelvan, Kadir, Basri \& Ayub, 2020; Mustafa Ozgene, 2020). The regression model with collaborative leadership, unity of purpose, learning partnership and teacher's collaboration which is school culture dimensions are contributed for $47.0 \%$ changes in variance of school effectiveness. Its reveal that there is other factor which is effect the school effectiveness (Duan, et al., 2018, Thiruchelvan et al., 2020). Both combination of school culture and school climate construct significantly contributed $52.5 \%$ variance changes of school effectiveness.

In particular, the dimension of school climate, leadership in primary schools is the highest contributing factor to school effectiveness. Based on the analysis of leadership plays the most important role and is a major factor in influencing the school climate (Carpenter, 2015). It is followed by dimension of instruction, expectations and environment. These four factors contribute to the school climate in primary schools in Malaysia. The finding confirms teachers' pay attention to students who are left behind and pay special attention in the classroom or outside of school hours. The school environment is generally conducive and very helpful for student learning in primary schools as stated by Patterson et al. (2014).

However, the aspect of collaboration still lacks attention such as engaging in school decision making by teachers and students. School management is still less encouraging teachers and students to speak up and give their views openly. This illustrates that superiors tend to make decisions in most situations which is not help solve the problem at the lower level (Gruenert, 2000). Parental involvement is another constraint faced by the school in shaping the school climate (Bellibas \& Liu, 2018). Parents and the community are still less involved in school activities causing the relationship between the two parties to remain loose. The problem of student attendance and irresponsibility is another constraint faced by the school in improving the effectiveness of the school.

The collaborative leadership dimension plays an important role as a key factor as a contributor to school culture. School leadership encourages teachers to work together and share ideas. Current issues are always informed to overcome the learning deficit by management. Teachers understand and support the mission of the school and strive towards it. Teachers found work together and take note of each other's teaching and spend time with each other which is help for school effectiveness (Hall \& Hord, 2015).

However, professional development and collegial support are still less prominent as contributing factors to primary school culture. Teachers are found to be less aware of the latest information in obtaining new ideas from seminars, conferences or other resources. In addition, teachers are less valued by colleagues and work in groups. This is due to time constraints and increasing workload in school management aspect (Norashid \& Hamzah, 2014). 


\section{Conclusion}

The purpose of this study was to determine the relationship between school culture and climate at primary schools. Influence of factors in the school culture dimensions and school climate dimensions for school effectiveness in primary schools identified through stepwise multiple linear regression.

Collaborative leadership, unity of purpose, learning partnership and teacher's collaboration are the school culture factors that should focus by school management to enhance ethos among staff. The leadership, instruction, expectations and environment also among school climate factors that must develop equally to provide better atmosphere for school effectiveness in entire nation.

In conclusion, the school culture and climate variables contributes to predicting the impact on school effectiveness as found Maxwell and Thomas (1991). The both school culture and climate are very important factor that in order to sustain school effectiveness (Bellibas \& Liu, 2018). The main findings of this study are the contribution of school culture and climate which contribute significantly to school effectiveness. Thus both construct play an important role in contributing to school effectiveness.

The findings of this study can explain that it contributes to the theory of school effectiveness where school culture and school climate contribute to the effectiveness of schools scientifically. However, further research needs to discern the nature of the cultural, ethical and community expectations of the type of schools with a focus upon improving student's outcomes and consolidating the primary and secondary schools.

\section{References}

Anderson, C. S. (1982). The search for school climate: A review of the research, Review of Educational Research, 52(3), 368-420.

Bates, R. J. (1987). Corporate culture, schooling and educational administration, Educational Administration Quarterly, 23(4), 79-115.

Bellibas, M. S., \& Liu Y. (2018). The effects of principals' perceived instructional and distributed leadership practices on their perceptions of School climate, International Journal of Leadership in Education, 21(2), 226-244.

Carpenter, D. (2015). School culture and leadership of professional learning communities, International Journal of Educational Management, 29(5), 682-694.

Chua, Y. P. (2009). Research Method (5 ${ }^{\text {th }}$ ed.). Kuala Lumpur: McGraw-Hill.

Clarke, J., Hall, S., Jefferson, T., \& Roberts, B. (1976), Subcultures, cultures and class: a theoretical overview, in S. Hall \& T. Jefferson (Eds) Resistance Through Rituals: Youth Subcultures in Post War Britain, (176-191). London: Hutchinson.

Diehr, G., \& Hoflin, D.R. (1974). Approximating the Distribution of the Sample R2 in Best subset regressions, Technometrics. 16, 317-320.

Duan, X., Du, X., \& Yu, K. (2018). School culture and school effectiveness: The mediating effect of teachers' job satisfaction, international, Journal of Learning, Teaching and Educational Research, 17(5), 15-25.

Glisson, C. (2007). Assessing and changing organizational culture and climate for effective services. Research on Social Work Practice, 17, 736-747. 
Glisson, C., \& Green, P. (2006). The effects of organizational culture and climate on the access to mental health care in child welfare and juvenile justice systems, Administration and Policy in Mental Health and Mental Health Services Research, 33(4), 433-448.

Glisson, C., \& Green, P. D. (2011). Organizational climate, services and outcomes in child welfare systems, Child Abuse and Neglect, 35(8), 582-591.

Gonder, P. O., \& Hymes, D. (1994). Improving school climate and culture: AASA critical issues report. Virginia: American Association of School Administrators.

Gruenert, S. (1998). Development of a School culture survey. Doctoral dissertation, University of Missouri - Columbia, 1998.

Gruenert, S. (2000). Shaping a new School culture, Contemporary Education, 71(2), 14-17.

Hall, G., \& Hord, S. (2015). Implementing change patterns, principles and potholes (4th ed.). Upper Saddle River, NJ: Person Education.

Hargreaves, D. H. (2001). A Capital Theory of School Effectiveness and Improvement, British Educational Research Journal, 27(4), 487-503.

Lewis J., Asberry J., DeJarnett, G., \& King G. (2016). The Best Practices for Shaping School culture for Instructional Leaders, Alabama Journal of Educational Leadership, 3, 57-63.

Maxwell, T. W., \& Thomas, A. R. (1991). School climate and school culture, Journal of Educational Administration, 29(2), 72-82.

Ozgene, M. (2020). An organizational factor predicting school effectiveness: school climate, International Journal of Psychology and Educational Studies, 7(1), 38-50.

Patterson, D. A., Dulmus, C. N., \& Maguin, E. (2012), Empirically supported treatment's impact on organizational culture and climate, Research on Social Work Practice, 22(6), 665-671.

Patterson, S. W., D. A., Dulmus, C. N., Maguin, E., \& Critalli, M. (2014). Do organizational culture and climate matter for successful client outcomes? Research on Social Work Practice, 24(6), 670-675.

Ross, S. M., \& Lowther, D. L. (2003). Impacts of the co-nect school reform design on classroom instruction, school climate, and student achievement in inner-city schools, Journal of Education for Students Placed at Risk, 8(2), 215-246.

Schein, E. H. (1985). Organizational Culture and Leadership: A Dynamic View. San Francisco: Jossey-Bass Publishers.

Schein, E. H. (1992). Organizational Culture and Leadership ( $3^{\text {rd }}$ ed.), San Francisco: JosseyBass Publishers.

Thiruchelvan, K., Kadir, S. A., Basri, R., \& Ayub, A. F. M. (2020). Influence of school culture and climate in tamil schools, Malaysia. International Journal of Academic Research in Business and Social Sciences, 10(5), 1-12.

Wang, M. C., Haertel, G. D., \& Walberg, H. J. (1997). Learning influences, in H.J. Walberg and G.D. Haertel (Eds), Psychology and Educational Practice (199-211). Berkley, CA: McCuthan. 